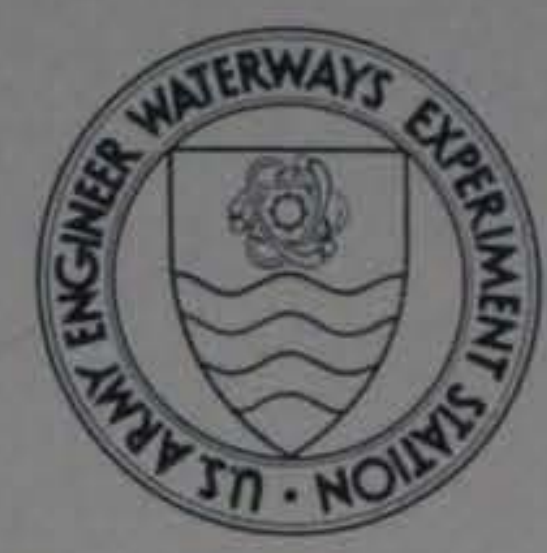

\title{
ABRASION-EROSION RESISTANCE OF FIBER-REINFORCED CONCRETE
}

by

Tony C. Liu, James E. McDonald

Structures Laboratory

U. S. Army Engineer Waterways Experiment Station

P. O. Box 631, Vicksburg, Miss. 39180

November 1981

Final Report

Approved For Public Release; Distribution Unlimited

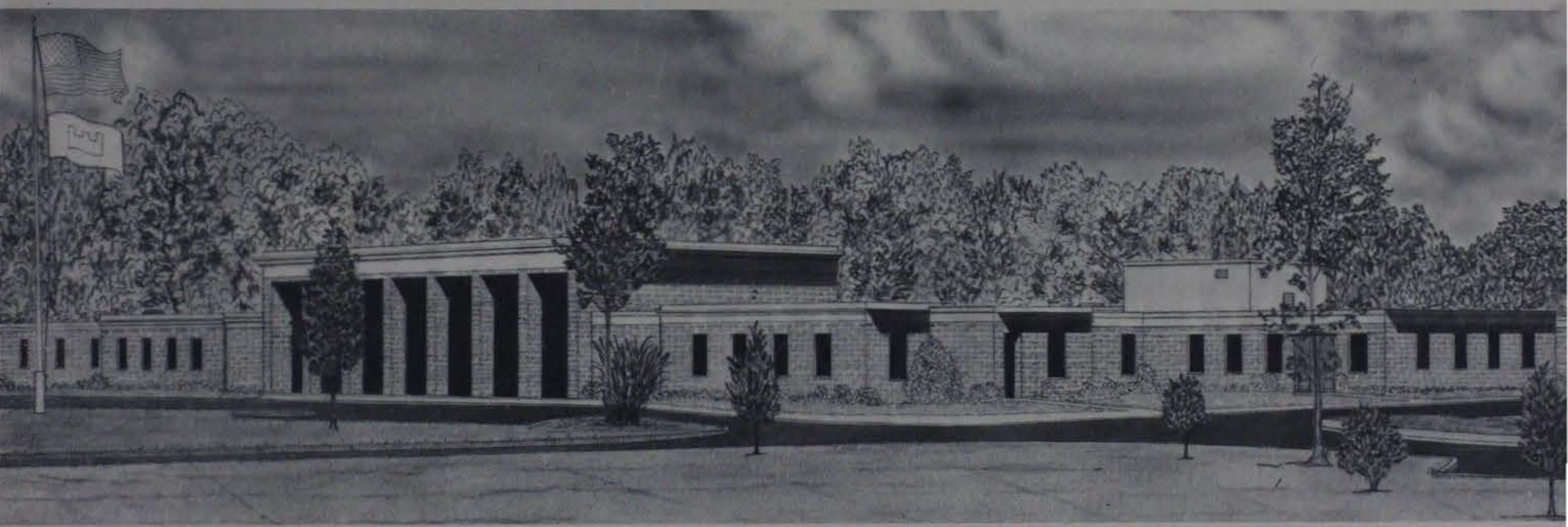

Prepared for Office, Chief of Engineers, U. S. Army Washington, D. C. 20314 


\begin{tabular}{|c|c|}
\hline $\begin{array}{l}\text { REPORT DOCUMENTATION PAGE } \\
\text { 1. REPORT NUMBER }\end{array}$ & $\begin{array}{l}\text { READ INSTRUCTIONS } \\
\text { BEFORE COMPLETING FORM }\end{array}$ \\
\hline $\begin{array}{l}\text { 1. REPORT NUMBER } \\
\text { Miscellaneous Paper SL-81-32 }\end{array}$ & 3. RECIPIENT'S CATALOG NUMBER \\
\hline $\begin{array}{l}\text { 4. TITLE (and Subtitle) } \\
\text { ABRASION-EROSION RESISTANCE OF } \\
\text { FIBER-REINFORCED CONCRETE }\end{array}$ & $\begin{array}{l}\text { 5. TYPE OF REPORT \& PERIOD COVERED } \\
\text { Final report }\end{array}$ \\
\hline 7. AUTHOR(A) & 6. PERFORMING ORG. REPORT NUMBER \\
\hline $\begin{array}{l}\text { 7. AUTHOR(o) } \\
\text { Tony C. Liu } \\
\text { James E. McDonald }\end{array}$ & 8. CONTRACT OR GRANT NUI ER(0) \\
\hline $\begin{array}{l}\text { 9. PERFORMING ORGANIZATION NAME AND ADDRESS } \\
\text { U. S. Army Engineer Waterways Experiment Station } \\
\text { Structures Laboratory } \\
\text { P. O. Box } 631 \text {, Vicksburg, Miss. } 39180\end{array}$ & $\begin{array}{l}\text { 10. PROGRAM ELEMENT, PROJECT, TASK } \\
\text { AREA \& WORK UNIT NUMBERS }\end{array}$ \\
\hline $\begin{array}{l}\text { 11. CONTROLLING OFFICE NAME AND ADDRESS } \\
\text { Office, Chief of Engineers, U. S. Army }\end{array}$ & $\begin{array}{l}\text { 12. REPORT DATE } \\
\text { November } 1981\end{array}$ \\
\hline Washington, D. C. 20314 & $\begin{array}{l}\text { 13. NUMBER OF PAGES } \\
26\end{array}$ \\
\hline 14. MONITORING AGENCY NAME \& ADDRESS(If different from Controlling Oflico) & $\begin{array}{l}\text { 15. SECURITY CLASS. (of this : port) } \\
\text { Unclassified }\end{array}$ \\
\hline & $\begin{array}{l}\text { 15a. DECLASSIFICATION/DOWNGRADING } \\
\text { SCHEDULE }\end{array}$ \\
\hline
\end{tabular}

Approved for public release; distribution unlimited.

17. DISTRIBUTION STATEMENT (of the abstract ontered in Block 20, if difforent from Report)

18. SUPPLEMENTARY NOTES

Available from National Technical Information Service, 5285 Port Royal Road, Springfield, Va. 22151.

19. KEY WORDS (Continue on reverse side If necessary and ldentlfy by block number)

Abrasion

Concrete erosion

Fiber reinforced concrete

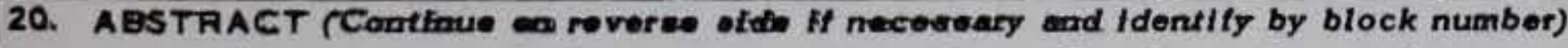

A recent laboratory study of the abrasion-erosion resistance of fiberreinforced concrete (FRC) is described in this report. FRC has been used for repair of abrasion-erosion damaged areas such as stilling basins, conduits, sluiceways, and discharge laterals in hydraulic structures. However, the resistance of such concrete subjected to abrasive action of waterborne particles had not previously been evaluated.

Thirteen concrete mixtures of three water-cement ratios 


\section{ABSTRACT (Continued)}

ranging from 0.40 to 0.72 , each containing one of four different types of steel fibers, were tested. As is true of concrete without steel fibers, the abrasionerosion resistance of FRC increased with decrease in water-cement ratio and consequent increase in compressive strength. The lengths of the fibers had very little effect on the abrasion-erosion resistance, and the FRC containing collated and hooked fibers had better abrasion-erosion resistance than the comparable concrete containing straight fibers.

A comparison of the performance of FRC and concrete not containing fibers clearly showed that FRC was less resistant to abrasion-erosion than concrete of the same aggregate type and water-cement ratio without fibers. The abrasionerosion losses of the FRC were consistently higher than those of the concrete not containing fibers over wide ranges of water-cement ratio and hence compressive strength.

Based on the results of laboratory tests and field performance experience, FRC is not recommended for use in new construction or repair of hydraulic structures where abrasion-erosion is a major concern. 


\section{PREFACE}

This report is a paper that was prepared for presentation at the American Society for Testing and Materials Symposium on Durability of Concrete in Orlando, Fla., December 1980. The paper was based on research conducted as part of Civil Works Investigational Work Unit 31553, "Maintenance and Preservation of Civil Works Structures." The study was performed by the Structures Laboratory (SL) of the U. S. Army Engineer Waterways Experiment Station (WES) under the sponsorship of the Office, Chief of Engineers, U. S. Army.

The study was conducted under the general supervision of $\mathrm{Mr}$. Bryant Mather, Chief, SL, and Mr. John M. Scanlon, Jr., Chief, Concrete Technology Division, SL. Messrs. Tony C. Liu and James E. McDonald prepared this report.

Directors of WES during the study and the publication of this report were COL N. P. Conover, CE, and COL T. C. Creel, CE. Technical Director was Mr. F. R. Brown. 


\section{CONTENTS}

$\underline{\text { Page }}$

PREFACE . . . . . . . . . . . . . . . . . . . . . . . 1

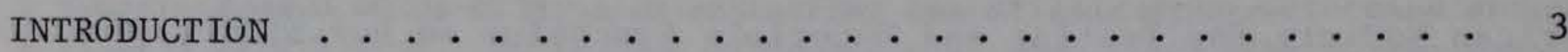

TEST METHOD DEVELOPMENT . . . . . . . . . . . . . . . . . . 4

TEST PROGRAM . . . . . . . . . . . . . . . . . . 5

Materials ..................... 5

Specimen Fabrication . . . . . . . . . . . . . 6

TEST RESULTS AND DISCUSSION . . . . . . . . . . . . . . . 7

Effects of Water-Cement Ratio . . . . . . . . . . . 7

Effects of Compressive Strength . . . . . . . . . . . 7

Effects of Concrete Type ... . . . . . . . . . . . . 8

Effects of Fiber Length and Type . . . . . . . . . . . 9

FIELD PERFORMANCE . . . . . . . . . . . . . . . . . . . 10

CONCLUSIONS AND RECOMMENDATION . . . . . . . . . . . . . . . 13

REFERENCES . . . . . . . . . . . . . . . . . . . . 15

TABLES $1-3$

FIGURES $1-11$ 


\section{INTRODUCTION}

A recent survey involving the various U. S. Army Corps of Engineers Divisions and Districts identified 52 structures that have experienced concrete damage due to abrasion-erosion. ${ }^{1}$ Depths of erosion ranged from a few inches (centimetres) to approximately $10 \mathrm{ft}$ (3 metres) (Figure 1). In general, this erosion damage resulted from the abrasive effects of waterborne rocks and other debris being circulated over and against the concrete surface during construction and operation of the structure.

The majority of the structures surveyed have been repaired, using a variety of materials and techniques with varying degrees of success. Repair materials included conventional concrete, epoxy resins, fiber-reinforced concrete, and polymer-impregnated concrete. In many instances, materials have been used in prototype repairs with limited or no laboratory evaluation of their effectiveness in the particular application. This survey showed a definite need for such material evaluations, particularly abrasion-erosion resistance, prior to using these materials in prototype repairs costing millions of dollars. Consequently, a comprehensive study was conducted at the U. S. Army Engineer Waterways Experiment Station to evaluate the relative abrasion-erosion resistance of various materials considered for use in repair of erosion-damaged concrete structures. The detailed test program and test results of this comprehensive study were reported in Reference 2.

Based on the test data obtained from this study, an evaluation of the abrasion-erosion resistance of fiber-reinforced concrete is presented in this paper. The available information on field performance of the FRC used to repair abrasion-damaged hydraulic structures is also presented. 
Various test methods have been used by investigators to determine abrasion resistance of a concrete surface. Among these are the rubbing types of apparatus, dressing wheel, shot-blast, rolling steel balls under pressure, and modified Los Angeles apparatus.

However, none of these existing test methods were considered to be satisfactory for evaluating the resistance of concrete subjected to the abrasive action of waterborne particles in a stilling basin. ${ }^{2}$ A new underwater abrasion test method was therefore devised. The apparatus consisted of essentially a. drill press, an agitation paddle (Figure 2), a cylindrical steel container that houses a disk-shaped concrete specimen, and 70 steel grinding balls of various sizes (ten 1-in. (25-mm)-diameter balls, thirty-five 0.75-in. (19-mm)-diameter balls, and twenty-five 0.50-in. (13-mm)-diameter balls). The detailed test setup is given in Figure 3.

The water in the container is circulated by the immersed agitation paddle that is powered by the drill press rotating at approximately $1200 \mathrm{rpm}$. The circulating water, in turn, moves the abrasive charges (steel grinding balls) on the surface of the concrete specimen, producing the desired abrasion effects (Figure 4). The average water velocity on the surface of the specimen as measured by a blunt-nose Pitot tube is approximately $6 \mathrm{ft} / \mathrm{sec}(1.8 \mathrm{~m} / \mathrm{sec})$. This water velocity and the agitation effect are not sufficient to lift the steel balls off the surface of the concrete specimen to cause significant impact action against the concrete being tested. The test specimens are weighed at 12-hr intervals during the 72-hr test period, and the relative abrasion-erosion resistance is evaluated by weight loss calculated according to the following equation: 
where

$$
L=\frac{M_{i}-M_{f}}{M_{i}} \times 100
$$

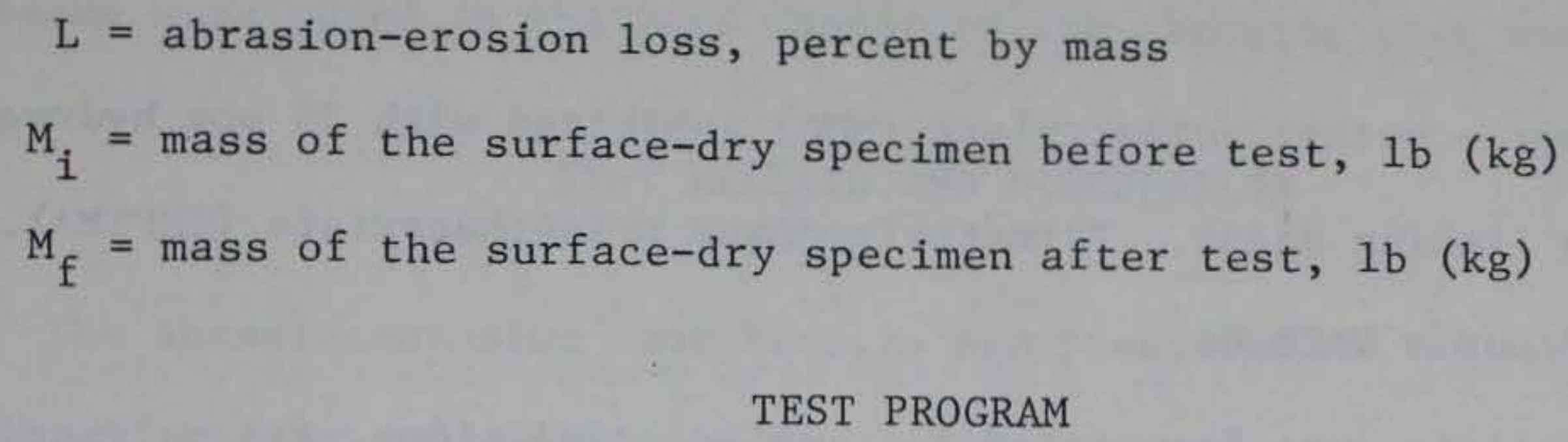

The comprehensive test program was designed to evaluate the relative abrasion-erosion resistance of various materials considered for use in the repair of erosion-damaged concrete hydraulic structures. As a part of the comprehensive test program, the abrasion-erosion resistance of FRC was evaluated and is presented herein.

A total of 13 concrete mixtures using 4 different types of steel fibers and 3 water-cement ratios ranging from 0.40 to 0.72 were tested (Table 1).

\section{Materials}

\section{Cement}

The cement used met the requirements of ASTM C 150-78 for Type I.

\section{Aggregates}

Crushed limestone aggregates were used for all concretes except Batches F9 and F10 where siliceous gravel was used.

\section{Steel fibers}

Four different types of steel fibers were used; two straight fibers and two hooked fibers. The nominal sizes of the straight steel fibers were 0.010 by 0.020 by $1 \mathrm{in}$. ( 0.25 by 0.50 by $25 \mathrm{~mm})$ and 0.010 by 0.020 by 0.5 in. (0.25 by 0.50 by $13 \mathrm{~mm}$ ). The nominal sizes of the hooked fibers were 2.0 by 0.02 in. ( 50 by $0.5 \mathrm{~mm}$ ) and 1.2 by $0.015 \mathrm{in.} \mathrm{(30} \mathrm{by} 0.4 \mathrm{~mm}$ ). 


\section{Monomer system}

The monomer system used for polymer-impregnated FRC (Batch F10) was as follows:

a. Monomer - methyl methacrylate (MMA) inhibited with $25 \mathrm{ppm}$ hydroquinone.

b. Cross linking agent - Trimethylpropane trimethacrylate (TMPTMA).

c. Initiator - VAZO 64 .

These materials were formulated for ambient conditions, and polymerization was achieved by addition of heat. Detailed procedures used for polymerization are given in Reference 2 .

\section{Mixture proportions}

The concrete mixture proportions for fiber-reinforced concretes are given in Table 2.

\section{Specimen Fabrication}

The concrete was mixed in a laboratory 7.5 -cu $\mathrm{ft}\left(0.21 \mathrm{~m}^{3}\right)$ rocking and tilting drum mixer in 5-cu ft $\left(0.14 \mathrm{~m}^{3}\right)$ batches. ${ }^{*}$ Each batch was tested for slump and air content according to ASTM C 143 and ASTM C 173, respectively.

Four 11-3/4-in. (298-mm)-diameter by 4-in. (102-mm)-high specimens were cast in specially designed molds. In addition to the abrasion specimens, three 6- by $12-i n$. (152- by $305-\mathrm{mm}$ ) cylinders and three 6 - by 6 - by $36-i n$. (152- by 152- by 914-mm) beams were cast for compressive strength and flexural strength tests, respectively. The concrete was placed in the mold using a scoop and consolidated on a vibrating table. The surface was finished by screeding and floating approximately $15 \mathrm{~min}$ after vibration, and final steel troweling was performed approximately $3 \mathrm{hr}$ after vibration. After $24 \mathrm{hr}$ in the fog room, the specimens

Batches F9 and F10 were made at Libby Dam during the repair of its stilling basin. 
were demolded and placed in the tank of lime-saturated water until test. All specimens were water cured for at least 28 days prior to testing. The cylinders and beams were cured in the same manner as the abrasion test specimens.

TEST RESULTS AND DISCUSSSION

The abrasion-erosion test results are presented in Table 3 . As previously stated, 13 batches of concrete were tested. In one or more of these batches, the effects on abrasion-erosion resistance of FRC of (a) water-cement ratio, (b) compressive strength, (c) concrete type, and (d) fiber length and type can be evaluated.

\section{Effect of Water-Cement Ratio}

The effect of water-cement ratio on abrasion-erosion resistance of FRC is shown in Figures 5 and 6 , where average abrasion-erosion losses, percent by mass, of FRC are plotted against test time. A reduction in water-cement ratio from 0.72 to 0.40 resulted in approximately 41 percent and 38 percent improvements in abrasion-erosion resistance (the reciprocal of abrasion-erosion loss) at $72 \mathrm{hr}$ for FRC containing $1-\mathrm{in} .(25-\mathrm{mm})$ and $0.5-\mathrm{in}$. (13-mm) straight steel fibers, respectively. The test results clearly indicated that for a given aggregate the abrasion-erosion resistance of FRC increased with decrease in watercement ratio.

\section{Effects of Compressive Strength}

The abrasion-erosion resistance of FRC having compressive strengths ranging from approximately 3,000 psi to $10,000 \mathrm{psi}(21$ to $69 \mathrm{MPa}$ ) was investigated. The relationship between abrasion-erosion loss at $72 \mathrm{hr}$ and compressive strength 
of FRC is shown in Figure 7. These curves indicated that the average abrasionerosion resistance of FRC increased approximately 46 percent as the compressive strength increased from $3,000 \mathrm{psi}(21 \mathrm{MPa})$ to $10,000 \mathrm{psi}(69 \mathrm{MPa})$. These data confirm the findings of other investigators ${ }^{3,4}$ who concluded that the abrasionerosion resistance of concrete increased with increase in compressive strength. However, the relationship was not generally linear. Figure 7 seemed to indicate, in general, that there was more improvement in abrasion-erosion resistance by increasing the compressive strength from $3000 \mathrm{psi}$ ( $21 \mathrm{MPa}$ ) to $6000 \mathrm{psi}$ (42 $\mathrm{MPa}$ ), and there appeared to be less advantage to increase the compressive strength above $6000 \mathrm{psi}(42 \mathrm{MPa})$.

\section{Effects of Concrete Type}

A comparison of the results of Batches T1 and F4 (Figure 8), which contain crushed limestone aggregates and have a water-cement ratio of 0.72 , indicated that the FRC was less resistant to abrasion-erosion than the concrete not containing fibers of the same aggregate type and water-cement ratio. The average 72-hr abrasion-erosion loss of FRC was approximately 22 percent higher than that of the concrete not containing fibers. Figure 9 indicated that the abrasion-erosion losses of FRC were consistently higher than those of the concretes not containing fibers over wide ranges of compressive strength. The poor performance of the FRC subjected to abrasion-erosion may be attributed to two factors.

a. The FRC generally has less coarse aggregate content per unit volume of concrete than that of the comparable concrete not containing fibers, and it has been shown ${ }^{2}$ that the coarse aggregate contributes significantly to the abrasion-erosion resistance of concrete. Therefore, it is reasonable to expect that the FRC is less resistant to abrasion-erosion than the concrete not containing fibers. 
b. When FRC is subjected to abrasion-erosion, the film of surface mortar resists the abrasion-erosion forces initially; but as the surface mortar is worn away, the fibers are exposed. The water flow and the movement of the abrasive charges in the test environment cause the exposed fibers to vibrate. As the fiber vibrates, it introduces large stresses in the concrete due to stress concentration. These large stresses contribute to further deterioration of the concrete around the fibers. The behavior was evidenced by the deteriorated concrete around the circumference of the fibers on the surface of the test specimens.

Batches F9 and F10 were fabricated by the U. S. Army Corps of Engineers, Seattle District, during the repair of Libby Dam stilling basin. They each contained siliceous gravel aggregates and 1.0-in. (25-mm) steel fibers. The F10 specimens were polymer-impregnated FRC similar to that used in 4-ft $(1.2 \mathrm{~m})$ sections along construction joints in the stilling basin. ${ }^{1}$ The abrasionerosion resistance of these materials is plotted in Figure 10. As expected, the abrasion-erosion resistance of polymer-impregnated FRC was significantly superior to the companion unpolymerized FRC. The average 72-hr abrasion-erosion resistance of FRC improved by approximately 45 percent by polymer-impregnation.

\section{Effects of Fiber Length and Type}

The effects of fiber length on the abrasion-erosion resistance of FRC can also be seen from Figure 7, where the average 72-hr abrasion-erosion losses of FRC containing $0.5-\mathrm{in} .(13-\mathrm{mm})$ and $1.0-\mathrm{in} .(25-\mathrm{mm})$ straight steel fibers are plotted against their compressive strengths. The lengths of the fiber being investigated apparently had very little effect on the abrasion-erosion resistance of FRC.

It was claimed that the collated and hooked fibers would improve workability, eliminate balling, and improve the static and dynamic properties of concrete. ${ }^{5}$ 
The abrasion-erosion resistance of FRC containing two sizes of hooked fibers, 1.2- (30-mm) and 2-in. (50-mm) lengths, was investigated. A comparison of the results of Batches F2, F5, F7, and F8, which contain crushed limestone aggregates and have a water-cement ratio of 0.54 , indicated that the abrasion-erosion loss of the FRC containing hooked fibers was approximately 16 percent less than that of the comparable FRC containing straight fibers (Figure 11). The improvement in abrasion-erosion resistance of concrete containing hooked fibers was probably due to the fact that there were fewer fibers in the concrete containing hooked fibers (e.g., $90 \mathrm{lb} / \mathrm{cu}$ yd $\left(53 \mathrm{~kg} / \mathrm{m}^{3}\right)$ of hooked fibers were used in Batches F7 and $\mathrm{F} 8$ and about $127.5 \mathrm{lb} / \mathrm{cu}$ yd $\left(76 \mathrm{~kg} / \mathrm{m}^{3}\right)$ of straight fibers were used in Batches F2 and F5) and therefore fewer stress raisers in the concrete containing hooked fibers.

\section{FIELD PERFORMANCE}

FRC has been used to repair erosion damage on three Corps of Engineers projects where follow-up evaluations of performance are available. These repairs at Kinzua Dam, Dworshak Dam, and Upper St. Anthony Falls Lock have been described in detail $1^{1}$ and are briefly discussed as follows.

\section{Kinzua Dam}

Unsymmetrical operation of the sluice at Kinzua Dam caused a circulatory current which carried debris into the stilling basin, the end sill being below streambed level. As a result, erosion of the concrete to depths of 42 in. ( $1 \mathrm{~m})$ was reported less than 4 years after the basin was placed into normal operation.

The deeper holes were partly filled with dense concrete having a 28-day compressive strength of 3000 psi (21 MPa). A concrete mixture containing 
1-in. (25-mm) steel fibers, proportioned for 1100- (8-MPa) and 6000-psi (42 MPa) flexural and compressive strengths, respectively, was used for the overlay.

A high modulus epoxy bonding compound was placed on the stilling basin floor immediately prior to placement of the FRC overlay. Approximately $1400 \mathrm{cu}$ yd $\left(1.070 \mathrm{~m}^{3}\right)$ of FRC were required for the overlay. The baffles were also repaired using FRC.

The initial diver inspection of the repair in November 1974,1 year after completion of the repairs, indicated minor concrete deterioration on some of the baffles and in the surrounding floor area. In April 1975, additional concrete erosion on five baffles and in the floor area between and downstream of the baffles was noted. Trenches around some baffles had approximate maximum depths of 4 to $12 \mathrm{in.}$ (102 to $305 \mathrm{~mm}$ ). The FRC overlay upstream of the baffles contained several areas of erosion ranging in depth from 5 to $17 \mathrm{in.}$ (127 to $432 \mathrm{~mm}$ ).

Continued erosion of the FRC was noted in subsequent inspections until a policy of symmetrical sluice operation was adopted. This appears to have essentially eliminated the problem of bringing rock, gravel, and other debris into the basin from downstream and, as a result, the rate of concrete erosion since September 1975 has been significantly reduced. Based on the experience at Kinzua, Armstrong ${ }^{6}$ stated that "the fibers do not provide any additional abrasion resistance to concrete, and in fact, the fiber-reinforced concrete seems to be less abrasion-resistant than normal concrete with large coarse aggregate."

\section{Dworshak Dam}

A 15-in. (318-mm)-thick FRC overlay was used for repair of Dworshak Dam stilling basin. Flexural and compressive strengths of the FRC were approximately 860 and 8000 psi ( 6 and $55 \mathrm{MPa}$ ), respectively, at 28-days age. The FRC was placed using a crane and two concrete buckets. Internal vibrators were used to 
consolidate the concrete and a vibrating screed was used to strike off the surface. Following the FRC placement, the right half of the stilling basin was impregnated with methyl methacrylate (MMA) monomer. 1

The underwater inspection by diver 7 months after completion of repairs indicated no major erosion or damage. The stilling basin walls had a small amount of surface erosion (less than 1 in. $(25 \mathrm{~mm}))$. There were several areas at the junction between the floor and wall with erosion up to 3 in. (75 $\mathrm{mm}$ ) deep. The FRC (both polymerized and nonpolymerized) was generally in good condition. In general, the polymer-impregnated side was probably a little better than the nonpolymerized side. There were several areas of erosion in the center of the basin several feet in diameter and dished out up to an inch (25 mm) deep. Joints and open cracks in the entire basin (including FRC) were the most susceptible to damage. Typical joints and open cracks in the FRC had eroded up to about $1 \mathrm{in.}(25 \mathrm{~mm})$ deep at the joint and tapered out to the original floor surface within a foot $(305 \mathrm{~mm})$ of the joint.

Four months later, after some additional usage of the stilling basin, a diver was employed to clean the debris from the basin and provide more information on the condition of the floor. Significant comments resulting from this inspection were that there were large areas of the concrete surface near the center of the basin with grooves 2 to $3 \mathrm{in.}$ ( 51 to $76 \mathrm{~mm}$ ) deep. These grooves, in both the polymerized and nonpolymerized FRC are oriented in the direction of flow.

\section{Upper St. Anthony Falls Lock}

The lock was dewatered in December 1975 to repair a damaged miter gate. During this period an examination of the filling and emptying laterals and discharge laterals revealed considerable abrasion-erosion of the concrete to maxi-

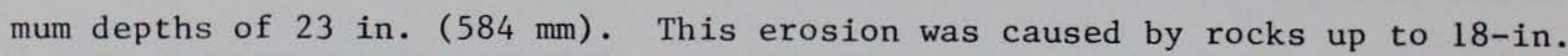


(457-mm) diameter which had made their way into the laterals. Subsequent filling and emptying of the lock during normal operation agitated these rocks causing them to erode the concrete.

Damaged concrete was removed from the discharge laterals with the use of hand power tools to a minimum depth of $3 \mathrm{in.} \mathrm{(76} \mathrm{mm),} \mathrm{and} \mathrm{all} \mathrm{damaged} \mathrm{reinforcing}$ steel was repaired or replaced. Approximately $40 \mathrm{cu}$ yd $\left(31 \mathrm{~m}^{3}\right)$ of $1-\mathrm{in}$. (25-mm) steel FRC was used in the repair of the discharge laterals. Average test results for this FRC were 965 and $6760 \mathrm{psi}$ ( 7 and $47 \mathrm{MPa}$ ) for flexural and compressive strengths, respectively, at 28-days age. In addition, a 1/2-in. (13-mm) steel FRC was used to repair a portion of the floor of one of the filling and emptying laterals. Average tests results were 730 and 5770 psi ( 5 and $40 \mathrm{MPa}$ ) for flexural and compressive strengths, respectively, at 28-days age.

Prior to filling the lock chamber, rocks that caused the erosion damage were returned to their original positions in the lateral to provide a positive test of the repairs. Approximately 2 years after the repairs dewatering of the lock allowed an examination of the repairs with results as follows:

The FRC in the discharge laterals was not subjected to the abrasive effects of waterborne rocks in the laterals, and erosion in these areas was negligible. In comparison, FRC in the filling and emptying lateral which was exposed to abrasion by rocks exhibited considerable erosion. At maximum depths (approximately 6 in.) erosion extended completely through the FRC repair and into the old concrete. The pattern and extent of erosion was almost identical to the adjacent conventional concrete repair.

CONCLUSIONS AND RECOMMENDATION

Based on the results of laboratory tests and field performance experience, it can be concluded that FRC is less resistant to abrasion-erosion than the 
concrete not containing fibers of the same aggregate type and water-cement ratio. The abrasion-erosion losses of the FRC are consistently higher than that of the concrete not containing fibers over wide ranges of water-cement ratio and hence compressive strength.

Therefore, FRC should not be used for new construction or repair of stilling basins or other hydraulic structures where abrasion-erosion is of major concern. Conventional concrete of the lowest practical water-cement ratio and the hardest available aggregate is recommended. 
1. McDonald, J. E., "Maintenance and Preservation of Concrete Structures, Report 2, Repair of Erosion Damaged Structures," Technical Report C-78-4 (Apr 1980), U. S. Army Engineer Waterways Experiment Station, Vicksburg, Miss.

2. Liu, T. C., "Maintenance and Preservation of Concrete Structures, Report 3, Abrasion-Erosion Resistance of Concrete," Technical Report C-78-4 (Sep 1980), U. S. Army Engineer Waterways Experiment Station, Vicksburg, Miss.

3. Kennedy, H. L. and Prior, M. "Abrasion Resistance," Special Technical Publication No. 169, American Society for Testing and Materials, Philadelphia, Penn., 1953.

4. Witte, L. P. and Backstrom, J. E. "Some Factors Affecting the Abrasion Resistance of Air-Entrained Concrete," American Society for Testing and Materials Proceedings, Vol 51, 1951.

5. "Dramix, a New Concrete Reinforcement," a leaflet by Bekaert Steel Wire Corporation, New York, 1975.

6. Presentation at the International Commission on Large Dams (ICOLD) XIII Congress, 1979, by Mr. R. C. Armstrong. 


\begin{tabular}{|c|c|c|c|c|c|c|c|c|c|}
\hline \multirow[b]{2}{*}{ Batch } & \multirow[b]{2}{*}{$\begin{array}{c}\text { Concrete } \\
\text { Type* } \\
\end{array}$} & \multirow[b]{2}{*}{$\begin{array}{l}\text { Aggregate } \\
\text { Type }\end{array}$} & \multirow[b]{2}{*}{$\begin{array}{c}\text { Fiber } \\
\text { Type/Length } \\
\text { in. (mm) } \\
\end{array}$} & \multirow[b]{2}{*}{$\begin{array}{r}\text { Comp. } \\
\text { Str., } \\
\text { psi (MPa) } \\
\end{array}$} & \multirow[b]{2}{*}{ 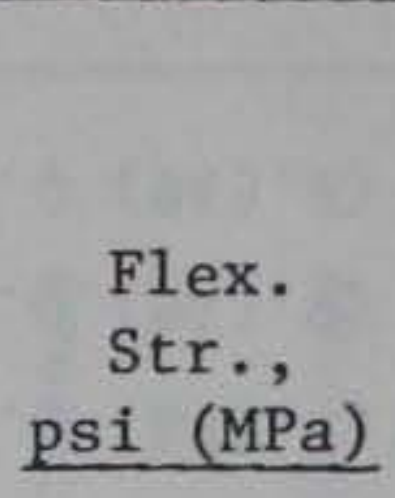 } & \multirow[b]{2}{*}{$\begin{array}{l}\text { Avg Abra- } \\
\text { sion Loss } \\
\text { at } 72-\mathrm{hr} \\
\% \\
\end{array}$} & \multicolumn{3}{|c|}{$\begin{array}{c}\text { Fresh Concrete } \\
\text { Properties } \\
\end{array}$} \\
\hline & & & & & & & $\begin{array}{l}\text { Water- } \\
\text { Cement } \\
\text { Ratio, } \\
\text { By Wt } \\
\end{array}$ & $\begin{array}{l}\text { Slump, } \\
\text { in. (mm) } \\
\end{array}$ & $\begin{array}{c}\text { Air } \\
\% \\
\end{array}$ \\
\hline $\mathrm{T} 1$ & $\mathrm{CC}$ & Limestone & -- & $3,470(24)$ & 675 (5) & 9.12 & 0.72 & $1-1 / 2$ & 6.0 \\
\hline T2 & $\mathrm{CC}$ & Limestone & -- & $6,870 \quad(47)$ & $920(6)$ & 6.12 & 0.54 & $6(152)$ & 1.1 \\
\hline T3 & $\mathrm{CC}$ & Limestone & -- & $9,820(68)$ & $1085(7)$ & 5.18 & 0.40 & $4-1 / 4(108)$ & 5.2 \\
\hline F1 & FRC & Limes tone & $\begin{array}{l}\text { Straight } \\
0.5 \text { (13) }\end{array}$ & $3,500 \quad(24)$ & 760 (5) & 9.73 & 0.72 & $1 / 2(13)$ & 6.6 \\
\hline F2 & FRC & Limestone & $\begin{array}{l}\text { Straight } \\
0.5(13)\end{array}$ & $6,920(48)$ & 949 (7) & 7.39 & 0.54 & 1 (25) & 1.9 \\
\hline F3 & FRC & Limestone & $\begin{array}{l}\text { Straight } \\
0.5 \text { (13) }\end{array}$ & $10,500(72)$ & $1070(7)$ & 6.04 & 0.40 & 1 (25) & 4.0 \\
\hline F4 & FRC & Limestone & $\begin{array}{l}\text { Straight } \\
1.0(25)\end{array}$ & $3,150(22)$ & 725 (5) & 11.17 & 0.72 & $1 / 4(6)$ & 6.6 \\
\hline F5 & FRC & Limestone & $\begin{array}{l}\text { Straight } \\
1.0(25)\end{array}$ & $5,770(40)$ & $1030(7)$ & 7.66 & 0.54 & $1-1 / 4 \quad(32)$ & 1.8 \\
\hline $\mathrm{F} 6$ & FRC & Limestone & $\begin{array}{l}\text { Straight } \\
1.0(25)\end{array}$ & $9,260 \quad(64)$ & $1080(7)$ & 6.64 & 0.40 & $2(50)$ & 5.0 \\
\hline F7 & FRC & Limestone & $\begin{array}{l}\text { Hooked } \\
2.0(50)\end{array}$ & $6,660(46)$ & $975(7)$ & 6.22 & 0.54 & $1-3 / 4(44)$ & 2.3 \\
\hline F8 & FRC & Limestone & $\begin{array}{l}\text { Hooked } \\
1.2(30)\end{array}$ & $7,370(51)$ & 970 (7) & 6.22 & 0.54 & $3(76)$ & 2.1 \\
\hline F9 & FRC & $\begin{array}{c}\text { Siliceous } \\
\text { Gravel }\end{array}$ & $\begin{array}{l}\text { Straight } \\
1.0(25)\end{array}$ & $6,420(44)$ & -- & 4.02 & 0.43 & $2-3 / 8 \quad(60)$ & 3.0 \\
\hline F10 & PC & $\begin{array}{l}\text { Siliceous } \\
\text { Gravel }\end{array}$ & $\begin{array}{l}\text { Straight } \\
1.0(25)\end{array}$ & $6,420(44)$ & -- & 2.20 & 0.43 & $2-3 / 8 \quad(60)$ & 3.0 \\
\hline
\end{tabular}




\section{Table 2 Concrete Mixture Proportions}

\begin{tabular}{|c|c|c|c|c|c|c|c|}
\hline Batch & $\begin{array}{c}1 \mathrm{~b} / \mathrm{cu} \text { yd } \\
\left(\mathrm{kg} / \mathrm{m}^{3}\right)\end{array}$ & $\begin{array}{c}1 \mathrm{~b} / \mathrm{cu} \text { yd } \\
\left(\mathrm{kg} / \mathrm{m}^{3}\right)\end{array}$ & $\begin{array}{l}\text { Coarse } \\
3 / 4 \text { in. to No. } 4 \\
1 \mathrm{~b} / \mathrm{cu} \text { yd }\left(\mathrm{kg} / \mathrm{m}^{3}\right) \\
\end{array}$ & $\begin{array}{c}\text { Fine } \\
1 \mathrm{~b} / \mathrm{cu} \text { yd } \\
\left(\mathrm{kg} / \mathrm{m}^{3}\right) \\
\end{array}$ & $\begin{array}{c}\text { Steel } \\
1 \mathrm{~b} / \mathrm{cu} \mathrm{yd} \\
\left(\mathrm{kg} / \mathrm{m}^{3}\right) \\
\end{array}$ & $\begin{array}{c}\text { Unit } \\
1 \mathrm{~b} / \mathrm{cu} \text { yd } \\
\left(\mathrm{kg} / \mathrm{m}^{3}\right)\end{array}$ & $\begin{array}{r}1 \mathrm{~b} / \mathrm{cu} \text { yd } \\
\left(\mathrm{kg} / \mathrm{m}^{3}\right) \\
\end{array}$ \\
\hline $\mathrm{T} 1$ & $277.2(164.4)$ & $385.0(228.4)$ & $1707.3(1012.9)$ & $1502.8(891.6)$ & -- & $143.4(85.1)$ & \\
\hline $\mathrm{T} 2$ & $354.6(210.4)$ & $656.7(389.6)$ & $1556.1 \quad(923.2)$ & $1484.0(880.4)$ & - & $150.1(89.1)$ & \\
\hline T3 & $290.1(172.1)$ & $708.0(420.0)$ & $1504.7 \quad(892.7)$ & $1435.4(851.5)$ & -- & $145.9(86.6)$ & \\
\hline F1 & $277.0(164.3)$ & $385.0(228.4)$ & $1664.0 \quad(987.2)$ & $1503.0(891.7)$ & $121.1(71.8)$ & $146.3(86.8)$ & \\
\hline F2 & $355.0(210.6)$ & $656.7(389.6)$ & $1511.0 \quad(896.4)$ & $1484.0(880.4)$ & $127.5(75.6)$ & $153.1(90.8)$ & \\
\hline F3 & $293.0(173.8)$ & $715.0(424.2)$ & $1400.0 \quad(830.6)$ & $1450.0(860.3)$ & $120.0(71.2)$ & $147.3(87.4)$ & \\
\hline F4 & $277.0(164.3)$ & $385.0(228.4)$ & $1664.0 \quad(987.2)$ & $1503.0(891.7)$ & $121.1(71.8)$ & $146.3(86.8)$ & \\
\hline F5 & $355.0(210.6)$ & $656.7(389.6)$ & $1511.0 \quad(896.4)$ & $1484.0(880.4)$ & $127.6(75.7)$ & $153.1(90.8)$ & \\
\hline F6 & $295.3(175.2)$ & $720.8(427.6)$ & $1411.1 \quad(837.2)$ & $1461.6(867.1)$ & $120.3(71.4)$ & $148.5(88.1)$ & \\
\hline F7 & $355.0(210.6)$ & $656.7(389.6)$ & 1522.0 (903.) & $1484.0(880.4)$ & $95.0(56.4)$ & $152.3(90.4)$ & \\
\hline F8 & $355.0(210.6)$ & $656.7(389.6)$ & $1522.0 \quad(903.0)$ & $1484.0(880.4)$ & $95.0(56.4)$ & $152.3(90.4)$ & \\
\hline F9 & $275.0(163.2)$ & $447.0(265.2)$ & $1353.0 \quad(802.7)$ & $1591.0(943.9)$ & $141.0(83.7)$ & $150.1(89.1)$ & $189(112.1)$ \\
\hline F10 & $275.0(163.2)$ & $447.0(265.2)$ & $1353.0 \quad(802.7)$ & $1591.0(943.9)$ & $141.0(83.7)$ & $150.1(89.1)$ & $189(112.1)$ \\
\hline
\end{tabular}


Table 3 Abrasion-Erosion Test Data

\begin{tabular}{|c|c|c|c|c|c|c|c|}
\hline \multirow[b]{2}{*}{ Batch } & \multirow{2}{*}{$\begin{array}{c}\begin{array}{c}\text { Specimen } \\
\text { No. }\end{array} \\
\end{array}$} & \multicolumn{6}{|c|}{ Abrasion-Erosion Loss, Percent by Mass } \\
\hline & & $12 \mathrm{hr}$ & $24 \mathrm{hr}$ & $36 \mathrm{hr}$ & $48 \mathrm{hr}$ & $60 \mathrm{hr}$ & $72 \mathrm{hr}$ \\
\hline T1 & 1 & 2.74 & 4.77 & 6.52 & 8.16 & 8.74 & 9.31 \\
\hline T1 & 2 & 1.65 & 3.38 & 5.64 & 6.83 & 8.24 & 8.43 \\
\hline T1 & 3 & 2.41 & 4.46 & 5.30 & 7.27 & 8.63 & 9.63 \\
\hline T1 & Average & 2.27 & 4.20 & 5.82 & 7.42 & 8.54 & 9.12 \\
\hline T2 & 1 & 1.72 & 3.00 & 4.24 & 5.24 & 5.80 & 6.32 \\
\hline T2 & 2 & 1.68 & 2.86 & 3.83 & 4.72 & 5.23 & 5.87 \\
\hline T2 & 3 & 1.61 & 2.85 & 3.42 & 4.46 & 5.16 & 6.17 \\
\hline $\mathrm{T} 2$ & Average & 1.67 & 2.90 & 3.83 & 4.81 & 5.40 & 6.12 \\
\hline T3 & 1 & 1.23 & 2.21 & 3.24 & 4.01 & 5.29 & 6.40 \\
\hline T3 & 2 & 1.20 & 1.70 & 2.47 & 3.10 & 3.82 & 4.71 \\
\hline T3 & 3 & 0.79 & 1.33 & 1.92 & 2.48 & 3.58 & 4.42 \\
\hline T3 & Average & 1.07 & 1.75 & 2.54 & 3.20 & 4.23 & 5.18 \\
\hline F1 & 1 & 1.87 & 3.68 & 5.14 & 5.68 & 8.07 & 9.94 \\
\hline F1 & 2 & 2.16 & 3.27 & 5.27 & 6.43 & 7.83 & 9.55 \\
\hline F1 & 3 & 2.30 & 3.84 & 4.90 & 6.75 & 8.21 & 9.70 \\
\hline F1 & Average & 2.11 & 3.60 & 5.10 & 6.29 & 8.04 & 9.73 \\
\hline F2 & 1 & 1.77 & 2.91 & 4.10 & 5.36 & 6.57 & 7.71 \\
\hline F2 & 2 & 1.19 & 1.97 & 3.08 & 4.59 & 5.93 & 7.06 \\
\hline F2 & Average & 1.48 & 2.44 & 4.03 & 4.98 & 6.25 & 7.39 \\
\hline F3 & 1 & 1.75 & 3.02 & 3.60 & 4.11 & 5.05 & 6.19 \\
\hline F3 & 2 & 1.62 & 2.63 & 3.52 & 4.10 & 5.55 & 6.26 \\
\hline F3 & 3 & 1.01 & 2.01 & 3.02 & 3.72 & 4.65 & 5.66 \\
\hline F3 & Average & 1.46 & 2.55 & 3.38 & 3.98 & 5.08 & 6.04 \\
\hline F4 & 1 & 4.39 & 7.96 & 9.95 & 11.37 & 12.14 & 12.40 \\
\hline F4 & 2 & 3.02 & 5.30 & 7.66 & 9.19 & 10.16 & 10.45 \\
\hline F4 & 3 & 2.79 & 5.95 & 7.96 & 9.71 & 10.13 & 10.65 \\
\hline F4 & Average & 3.40 & 6.40 & 8.52 & 10.09 & 10.81 & 11.17 \\
\hline F5 & 1 & 0.91 & 1.89 & 3.03 & 3.74 & 4.93 & 6.82 \\
\hline F5 & 2 & 1.45 & 2.96 & 4.21 & 5.63 & 6.79 & 8.24 \\
\hline F5 & 3 & 1.82 & 3.24 & 4.23 & 6.03 & 6.73 & 7.92 \\
\hline F5 & Average & 1.39 & 2.70 & 3.82 & 5.13 & 6.15 & 7.66 \\
\hline F6 & 1 & 1.31 & 2.12 & 3.24 & 4.21 & 5.60 & 6.38 \\
\hline F6 & 2 & 1.31 & 2.49 & 3.53 & 4.58 & 6.41 & 7.28 \\
\hline F6 & 3 & 0.90 & 2.01 & 2.84 & 3.48 & 4.59 & 6.27 \\
\hline F6 & Average & 1.17 & 2.21 & 3.20 & 4.09 & 5.53 & 6.64 \\
\hline F7 & 1 & 1.35 & 3.00 & 3.90 & 5.17 & 6.31 & 6.70 \\
\hline F7 & 2 & 1.08 & 1.88 & 2.96 & 3.84 & 5.40 & 5.65 \\
\hline F7 & 3 & 1.31 & 2.78 & 3.79 & 4.93 & 5.99 & 6.32 \\
\hline F7 & Average & 1.25 & 2.55 & 3.55 & 4.65 & 5.90 & 6.22 \\
\hline F8 & 1 & 1.14 & 2.34 & 3.23 & 4.40 & 5.59 & 6.35 \\
\hline F8 & 2 & 1.13 & 2.11 & 3.47 & 4.42 & 5.19 & 6.23 \\
\hline F8 & 3 & 1.18 & 2.30 & 3.33 & 4.30 & 5.12 & 6.20 \\
\hline F8 & Average & 1.15 & 2.25 & 3.34 & 4.37 & 5.30 & 6.22 \\
\hline
\end{tabular}

(Continued) 
Table 3 (Concluded)

\begin{tabular}{|c|c|c|c|c|c|c|c|}
\hline \multirow[b]{2}{*}{ Batch } & \multirow{2}{*}{$\begin{array}{c}\text { Specimen } \\
\text { No. }\end{array}$} & \multicolumn{6}{|c|}{ Abrasion-Erosion Loss, Percent by Mass } \\
\hline & & $12 \mathrm{hr}$ & $24 \mathrm{hr}$ & $36 \mathrm{hr}$ & $48 \mathrm{hr}$ & $60 \mathrm{hr}$ & $72 \mathrm{hr}$ \\
\hline F9 & 1 & 9.90 & 1.76 & 2.39 & 2.85 & 3.48 & 4.48 \\
\hline F9 & 2 & 0.81 & 1.29 & 1.62 & 2.37 & 2.80 & 3.56 \\
\hline F9 & Average & 0.86 & 1.53 & 2.00 & 2.61 & 3.14 & 4.02 \\
\hline F10 & 1 & 0.49 & 0.82 & 1.18 & 1.59 & 1.86 & 2.19 \\
\hline F10 & 2 & 0.54 & 0.81 & 1.07 & 1.61 & 1.88 & 2.20 \\
\hline F10 & Average & 0.52 & 0.82 & 1.13 & 1.60 & 1.87 & 2.20 \\
\hline
\end{tabular}




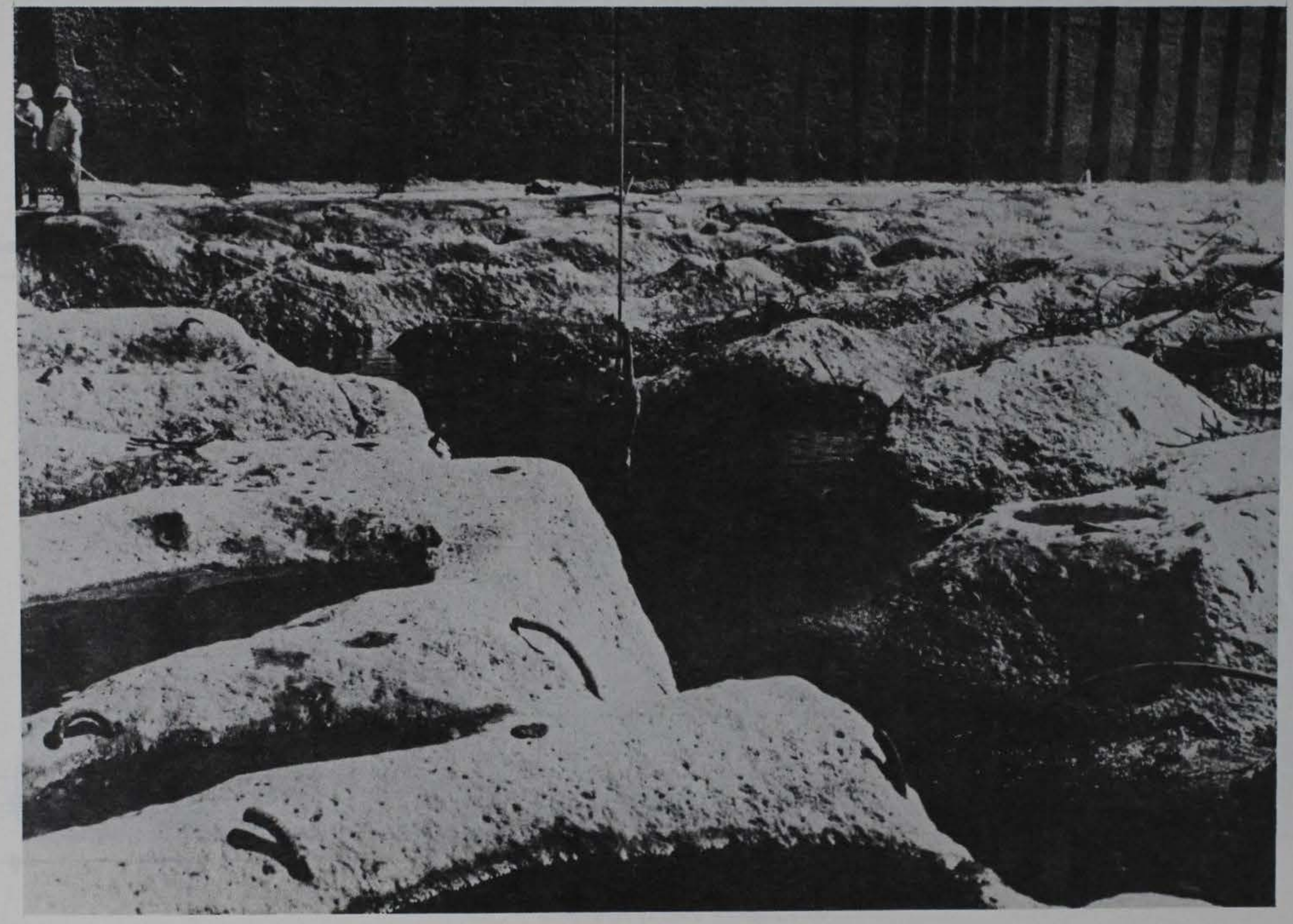

Figure 1. Erosion of stilling basin floor slab, Dworshak Dam 


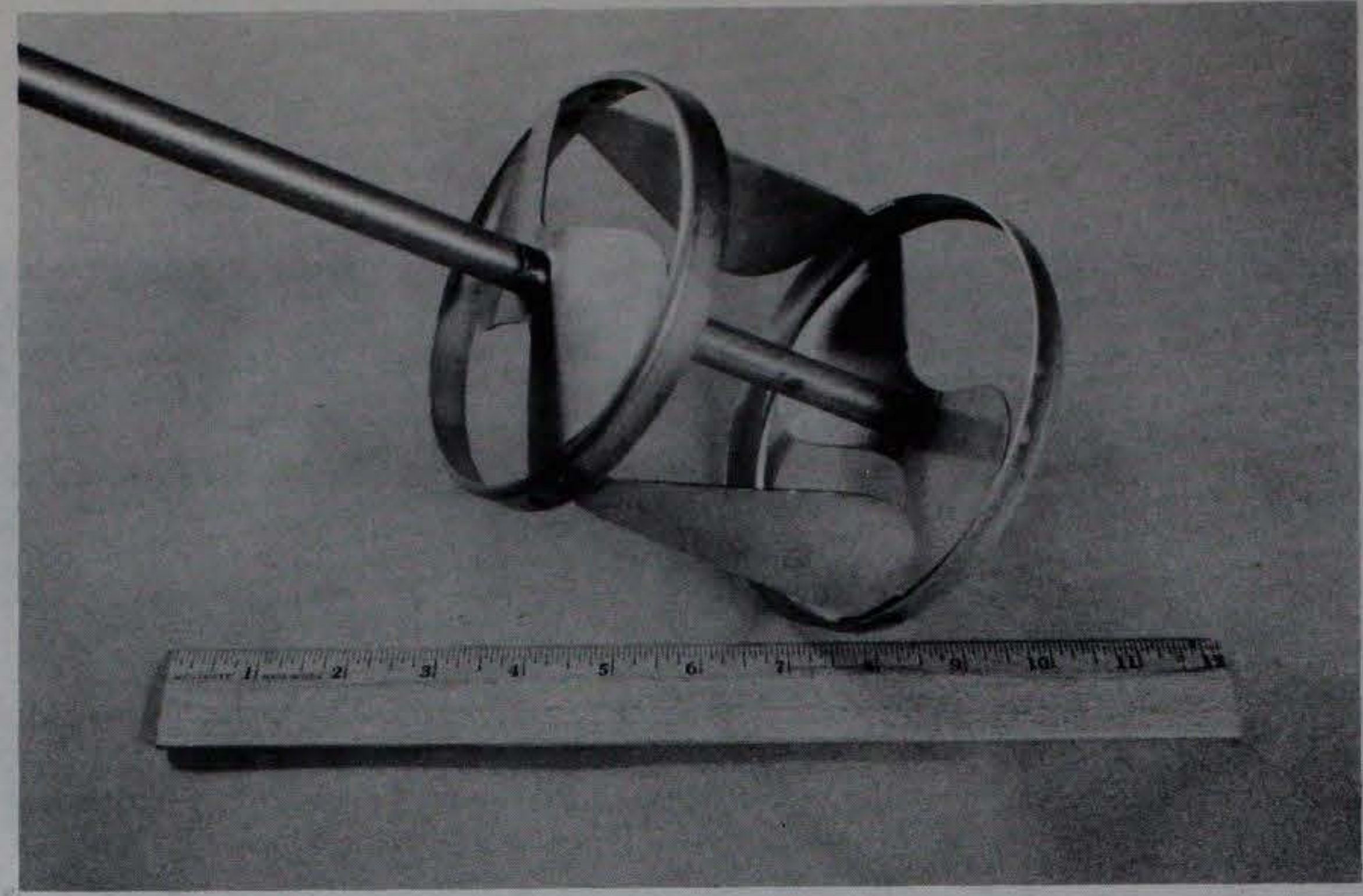

Figure 2. Agitation paddle

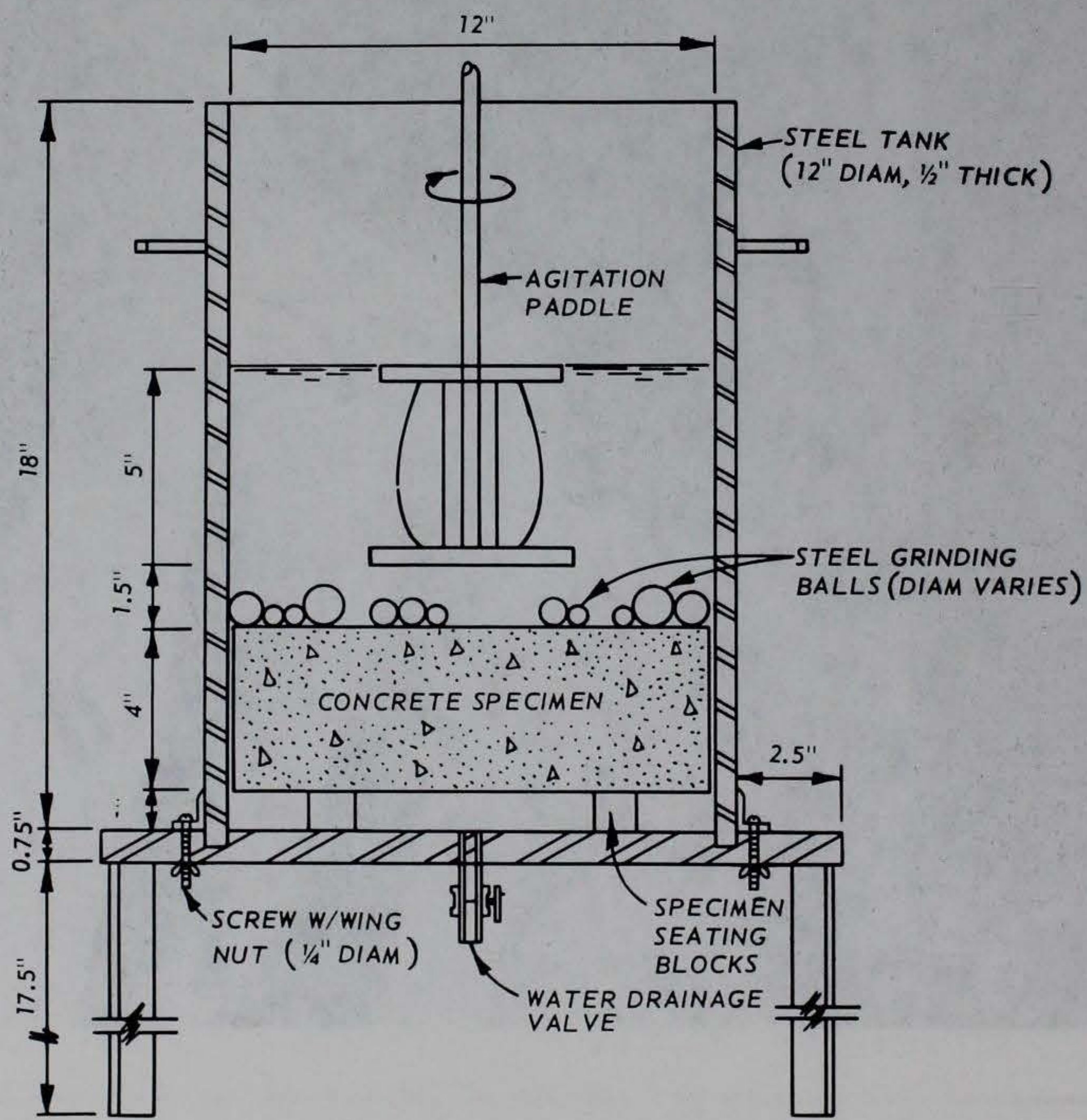

Figure 3. Test setup details 


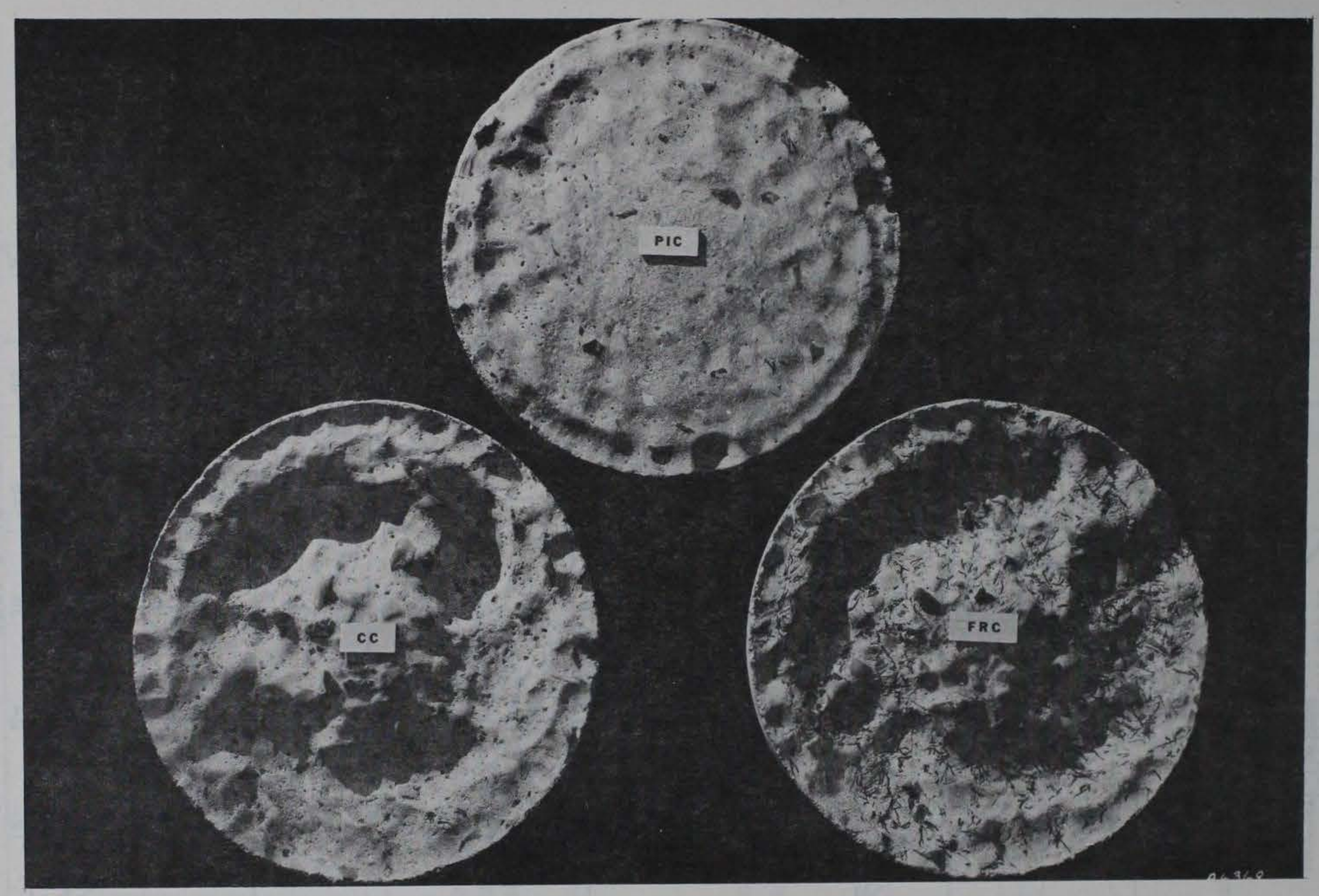

PIC - Polymer-impregnated Concrete

CC - Conventional Concrete

FRC - Fiber-reinforced Concrete

Figure 4. Eroded surface of typical test specimens 


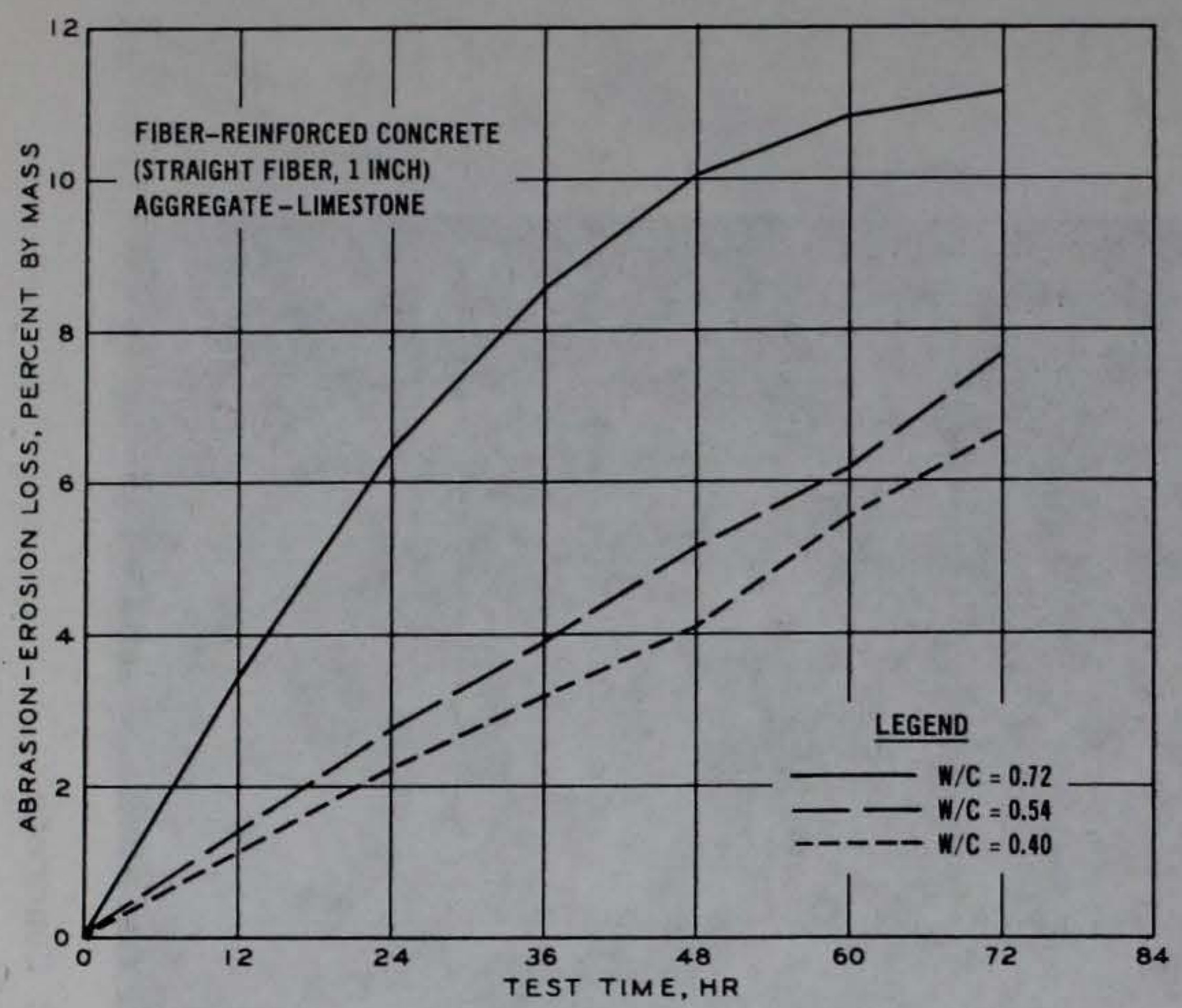

Figure 5. Effects of water-cement ratio on abrasionerosion resistance of fiber-reinforced concrete, 1-in. straight fiber

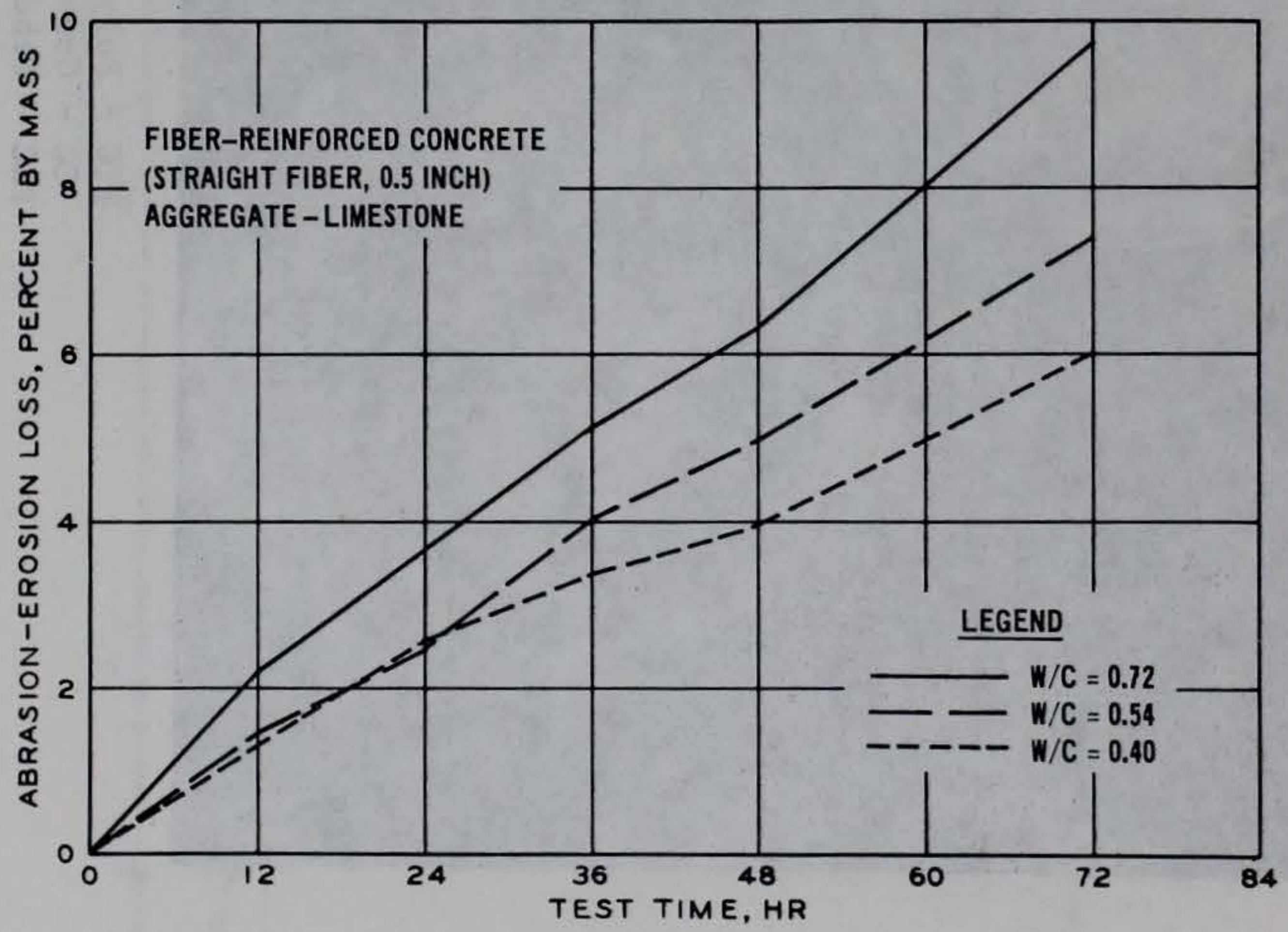

Figure 6. Effects of water-cement ratio on abrasionerosion resistance of fiber-reinforced concrete, 0.5-in. straight fiber 


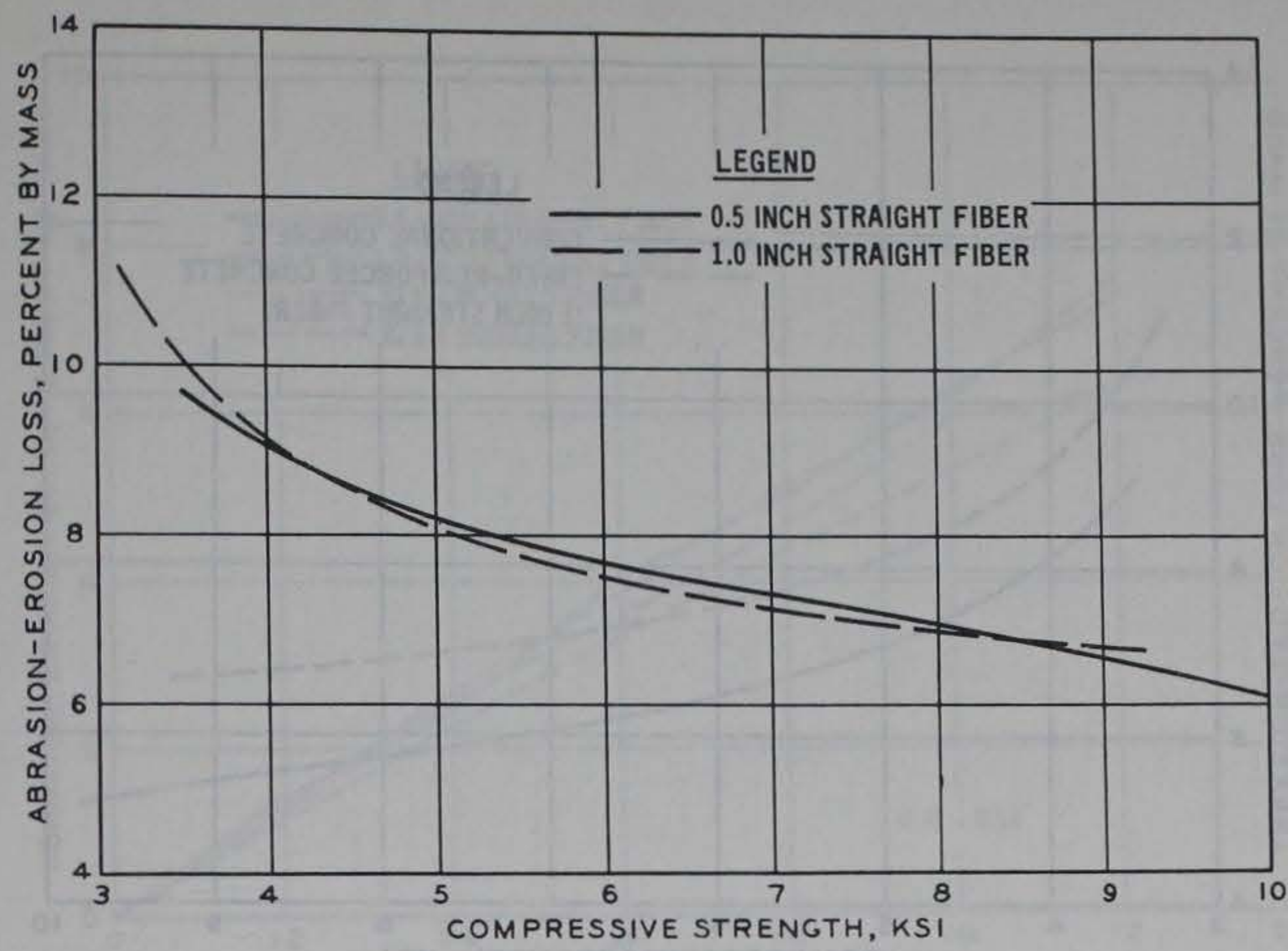

Figure 7. Relationship between abrasion-erosion resistance and compressive strength of fiber-reinforced concrete

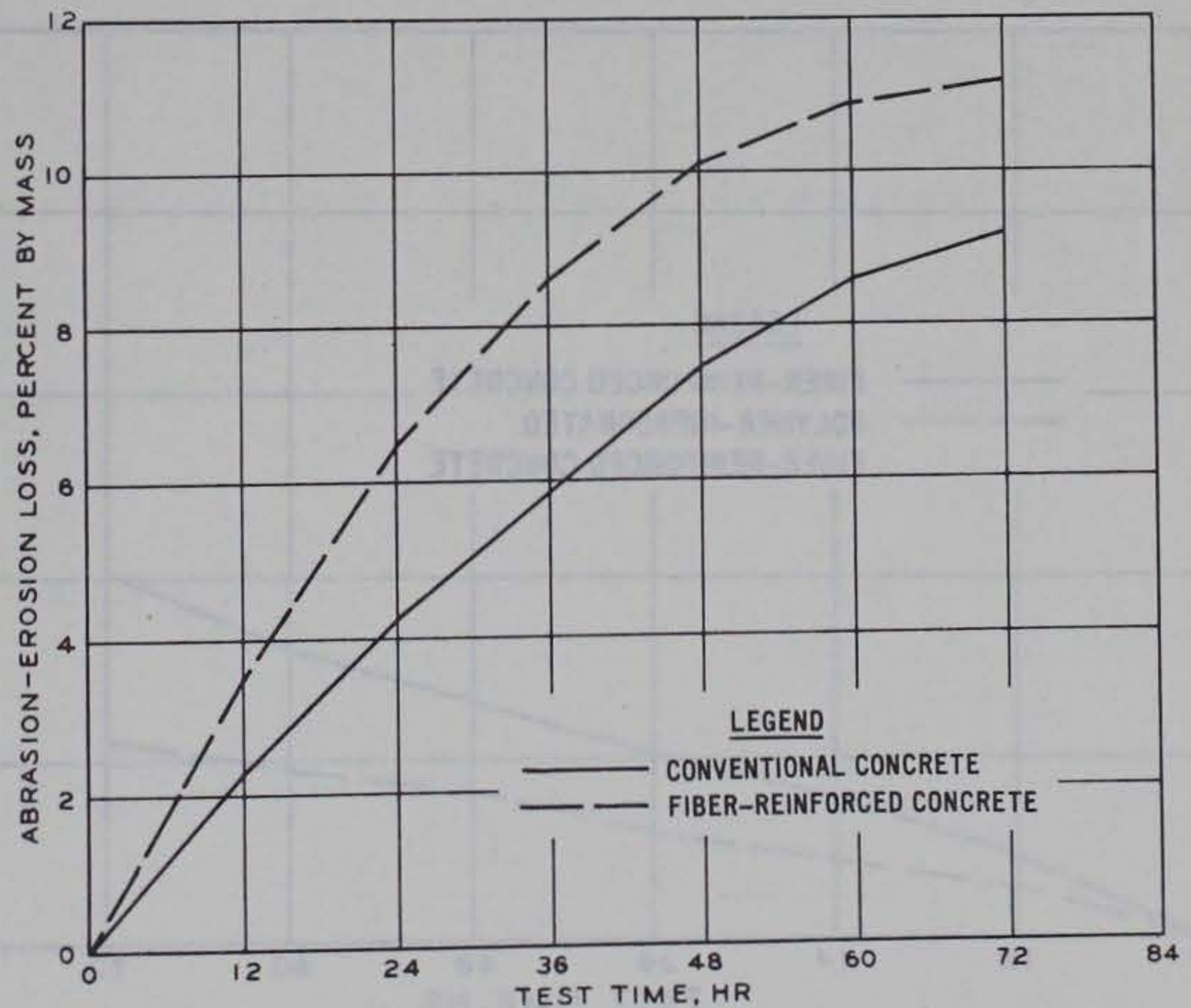

Figure 8. Effects of concrete type on abrasionerosion resistance $(\mathrm{W} / \mathrm{C}=0.72$, limestone aggregate) 


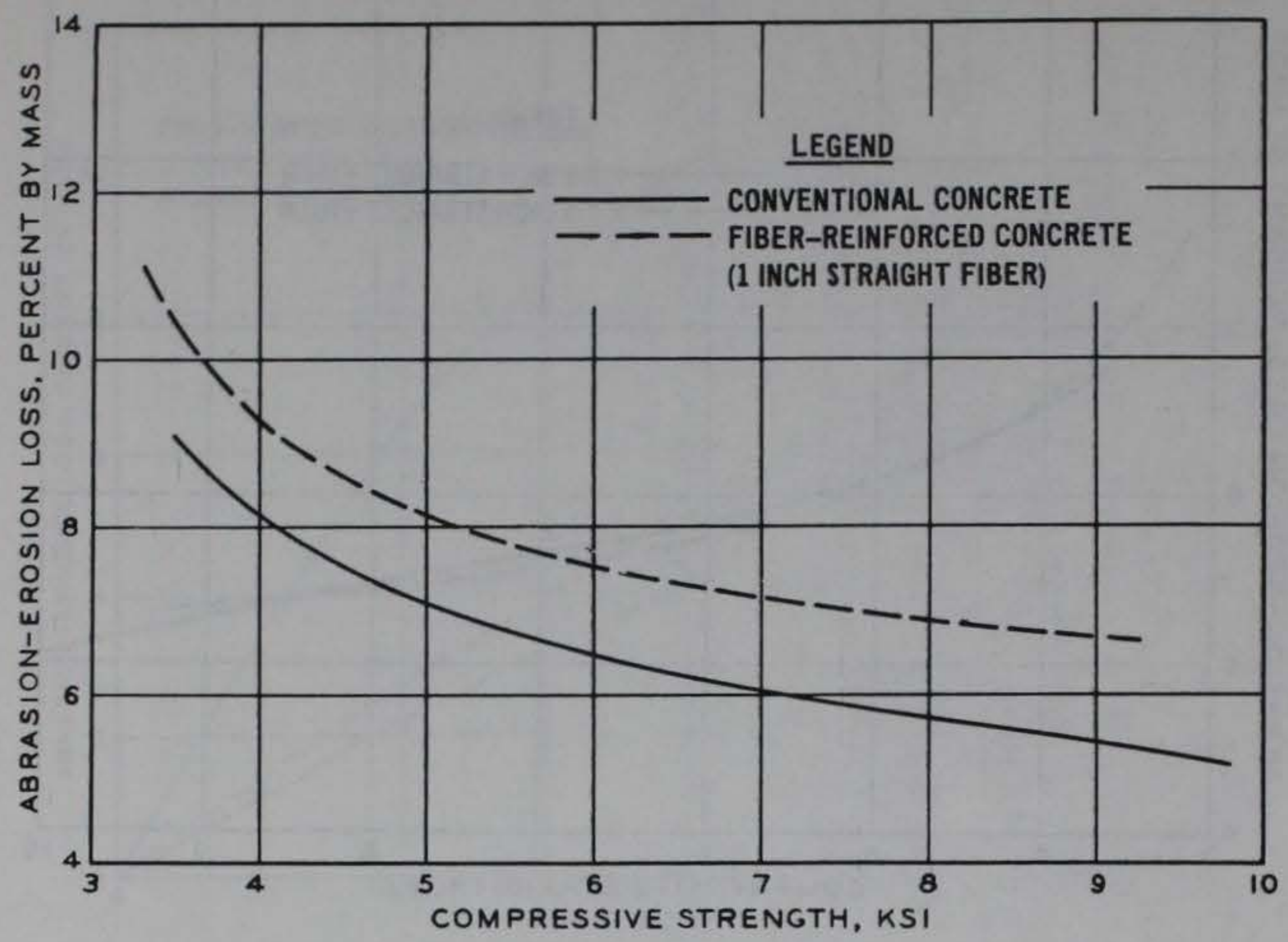

Figure 9. Relationship between compressive strength and abrasion-erosion resistance of conventional concrete and fiber-reinforced concrete

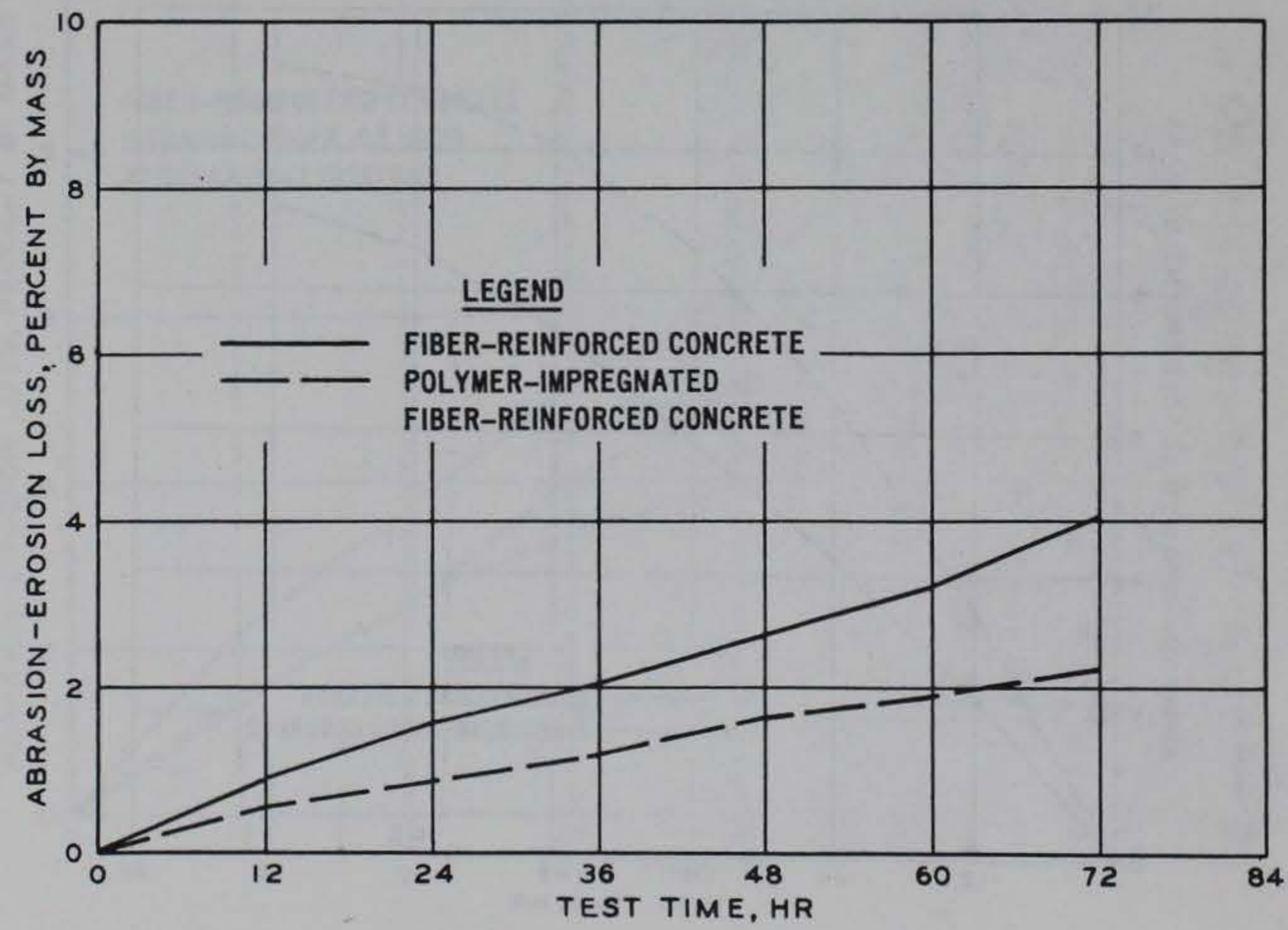

Figure 10. Abrasion-erosion resistance of fiber-reinforced concrete and polymer-impregnated fiber-reinforced concrete 


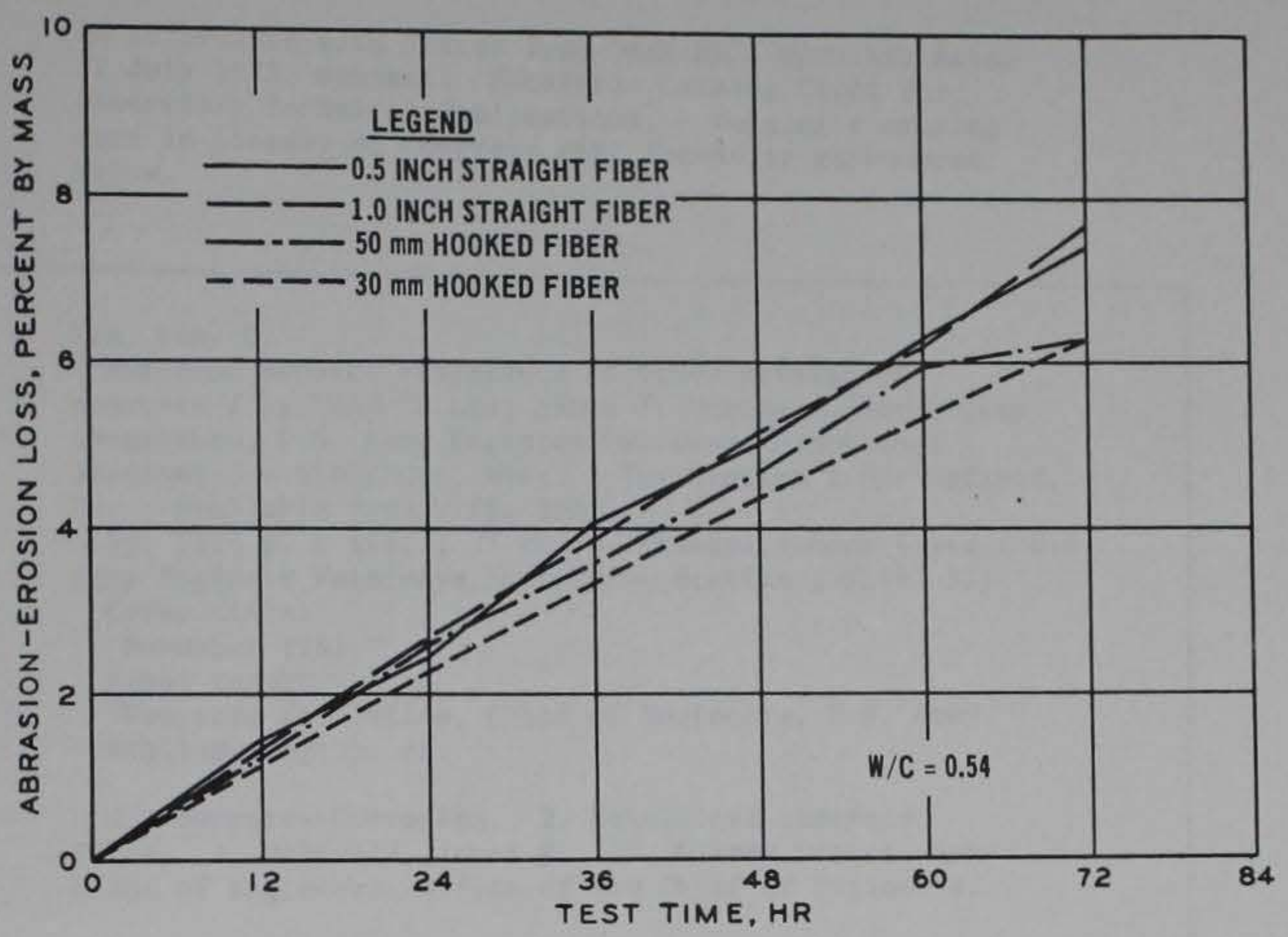

Figure 11. Abrasion-erosion resistance of fiber-reinforced concretes containing straight fibers and hooked fibers 